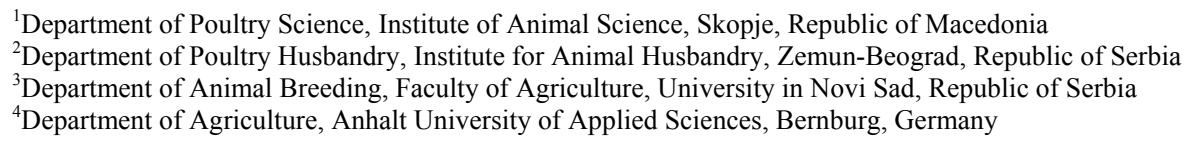
WAHNER $^{4}$

\title{
Influence of heat stress and age on the percentage of calcium carbonate in eggshell and the percentage of broken and cracked eggs
}

\begin{abstract}
The influences on eggs of high temperatures and age were examined in hens that were from a poultry farm situated in the south of the Republic of Macedonia where the average summer temperatures were always the highest. The experiment lasted for 9 months and comprised a period of three seasons: summer, autumn and winter. Maximum and minimum temperatures and relative humidity were recorded every day. Layers were of two different ages. During the research, all production parameters were recorded for the flocks: egg production, mortality, feed-consumption, body weight and the percentage of broken and cracked eggs. Once a month 50 eggs out of each age group were examined. An analysis of egg mass, eggshell mass and percentage of calcium carbonate in the eggshell was performed. At the end of the research the results underwent statistically analysis according to the Least Squares Means method. High temperatures in the region had a highly significant influence $(<0.01)$ over egg size, which was smaller than the average. The heat stress showed high significance $(<0.01)$ in relation to the percentage of calcium carbonate in the egg shell, which was lowest in the summer months and highest during the winter months. The age of the layers did not exhibit significant differences in any parameter examined. The percentage of broken and cracked eggs per month was highest in the summer period.
\end{abstract}

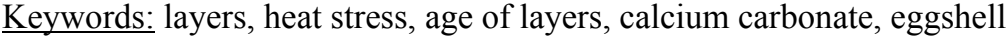

\section{Zusammenfassung}

Titel der Arbeit: Einfluss von Hitzestress auf den prozentualen Gehalt von Kalziumkarbonat in der Eischale sowie auf den Anteil von Bruch- und Knickeiern von unterschiedlich alten Legehennen

Es wurde der Einfluss der Umgebungstemperatur im Sommer, Herbst und Winter bei Tieren zweier Altersgruppen auf Merkmale der Legeleistung und der Eischalenqualität untersucht. Die Eier stammten von einer Farm im Süden der Republik Mazedonien, wo die durchschnittlich höchsten Sommertemperaturen herrschen. Es wurden sowohl die minimalen und maximalen Werte der Temperatur und der relativen Luftfeuchtigkeit als auch alle Produktionskennzahlen wie Legeleistung, Tierverluste, Futteraufnahme, Körpergewicht und der Prozentsatz von Bruch- und Knickeiern täglich erfasst. Monatlich einmal wurden 50 Eier von jeder Altergruppe nach folgenden Parametern zusätzlich untersucht: Eimasse, Eischalenmasse und prozentualer Gehalt von Kalziumkarbonat in der Schale. Alle Ergebnisse wurden nach der Lean Squares Methode statistisch verarbeitet. Hohe Umgebungstemperaturen hatten unabhängig vom Alter der Tiere einen hoch signifikanten $(<0,01)$ negativen Einfluss auf die Legeleistung. Ferner wirkte sich der Hitzestress auf den Kalziumkarbonatgehalt in der Schale signifikant negativ aus $(<0,01)$. In den Sommermonaten wurden die niedrigsten und in den Wintermonaten die höchsten Werte ermittelt. Der monatliche Prozentsatz an Bruch- und Knickeiern war in der Sommerperiode am höchsten. Ein nennenswerter Einfluss des Alters der Hennen auf die untersuchten Parameter lag nicht vor. 


\section{Introduction}

Eggshell quality is a major concern in the egg industry. Economic losses associated with the incidence of eggshell defects are important when evaluating the profitability of a layer operation (BELL, 1998; FLOCK, 1995; SEELAND et al., 1995). Low egg quality almost leads to a 5-8\% loss in production (KESHAVARZ, 1994). The frequency of defective eggs may increase from 7-11\% during the laying, collecting and packing stages of egg production. Thus shell quality in the egg is one of the major problems of egg production. Maintaining quality eggshells throughout the production cycle is desirable. Avian eggshell contains organic (3.5\%) and inorganic $(95 \%$, almost calcium carbonate) fractions; it weighs about $5 \mathrm{~g}$ and contains $2.2 \mathrm{~g}$ calcium, which represents about $38 \%$ of its weight (NYS et al., 1999).

Many factors have been found to affect eggshell quality, such as disease, nutritional status of the flock, heat stress and age (ROBERTS, 2004). A decrease in eggshell quality of older hens has been reported by ELAROUSSI et al. (1994). Egg production rate decreases and egg weight increases as age advances, also egg composition change and shell thickness decrease with production level and age of layer (SUMMERS and LEESON, 1983; SEELAND et al., 1995; MACHAL and SIMEONOVOVA, 2002). The decline in eggshell quality as the hens' age may in part be attributed to reduced intestinal calcium uptake as well as to increased egg size (AL-BATSHAN et al., 1994). The increase in shell weight as hens' age was not sufficient to compensate for the increased egg weight, so that the ratio of shell weight to egg weight decreased (ROBERTS and BLANEY, 2000).

The aim at the present study was to determine the influence of hens' age and high temperatures on the eggshell quality.

\section{Materials and methods}

Eggs from a poultry farm in the south of the Republic of Macedonia were used as material in the trial and which was under the influence of Mediterranean climatic temperatures. High summer temperatures emerge as being common and normal, and they are also higher than the average summer temperatures of the remainder of the country's regions. The trial encompassed the summer, autumn and winter season over a period lasting 9 months. During this period the daily maximum and minimum temperatures were observed, as well as the relative humidity.

The eggs from three layer flocks of the ISA-BROWN line were taken for the examination, with differing ages during the research period, where all the production parameters were used to exemplify the entire productive year by production stages, for factors such as mortality, body weight, feed consumption, egg production and the number of broken and cracked eggs.

Egg production and cracked eggs evidence comprised three stages of the laying period: the first stage, covered the first five months, the second stage featured the next five months, and finally, the last two months of annual egg production, were covered by the third stage. The layer flock's feeding was adequate for their age and season. The main aim was to lower the influence of the nutritional factor under eggshell quality changes.

The material was taken from two groups of layers of different ages, the first one comprised layers up to 45 weeks of age, or younger layers, and the second group's 
eggs were from layers more then 45 weeks of age or older. 50 eggs from both groups were collected monthly for examination under laboratory conditions by a Cramer titrimetric method: for egg weight, shell weight and percentage of $\mathrm{CaCO}_{3}$ (calcium carbonate) in the eggshell. The total number of eggs investigated was 877 . The data was analyzed by the least squares method with the assistance of the "Mixed Model Least Squares and Maximum Likelihood Computer Program” (HARVEY, 1990).

\section{Results}

The average of temperatures reached their maximum in the summer period, mainly in July, with 26.7 , and the minimum in December with 6.3 (Table 1). The winter period produced the highest relative humidity in December with $85.2 \%$, while in July the relative humidity level reached $47.5 \%$, which is counted as a high for that time of year (Table 2).

Table 1

Monthly temperatures in the investigation region

(Monatliche Umgebungstemperaturen in der Untersuchungsregion)

\begin{tabular}{lcccccccccc}
\hline $\begin{array}{l}\text { Monthly } \\
\text { temperatures in }\end{array}$ & July & Aug & Sept & Oct & Nov & Dec & Jan & Feb & Mar \\
\hline Minimum & 16.2 & 12.5 & 8.4 & -5 & -6 & -6 & -8 & -6 & -8 \\
Maximum & 41.7 & 35.2 & 35.8 & 30.2 & 21.8 & 17 & 19.5 & 22.2 & 21.5 \\
Average & 26.7 & 24.7 & 20.9 & 13.6 & 10.3 & 6.3 & 6.5 & 9.5 & 7.9 \\
\hline
\end{tabular}

Table 2

Monthly relative humidity in the investigation

(Monatliche relative Luftfeuchtigkeit in der Untersuchungsregion)

\begin{tabular}{llcccccccc}
\hline $\begin{array}{l}\text { Monthly relative } \\
\text { humidity in \% }\end{array}$ & July & Aug & Sept & Oct & Nov & Dec & Jan & Feb & Mar \\
\hline Minimum & 18 & 22 & 20 & 20 & 34 & 30 & 32 & 20 & 20 \\
Maximum & 96 & 100 & 100 & 100 & 100 & 100 & 100 & 100 & 100 \\
Average & 47.5 & 55.6 & 62.6 & 68.6 & 81.7 & 85.2 & 76.7 & 63.8 & 38.2 \\
\hline
\end{tabular}

In table 3 are the production results of the investigation layer flocks, participated in the trial.

In the first stage the egg carrying capacity rapidly grows and is distinguished with the peak production at over $90 \%$ - which is continued over the next few months with an average of 26.18 eggs produced monthly. The percentage of broken and cracked eggs was lowest at $1.29 \%$ in the younger layers, as a result of their ability to achieve the highest calcium retention from the feed, amounting to more than $2.0 \mathrm{~g}$ daily.

In the second stage, egg production exhibited a slow trend to decrease within a range of $88 \%$ down to $75 \%$, as well as at the same time increasing and maintaining egg weight. Monthly average egg production was 24.90 , while the amount of broken and cracked eggs in this stage increased by $2.53 \%$ because of the decreased Ca retention of from 1.5 to $1.7 \mathrm{~g} / \mathrm{per}$ bird/daily. The increased necessity of $\mathrm{Ca}$ for the production of bigger eggs, and on the other hand decreased $\mathrm{Ca}$ retention, contributes to weaker eggshell production and as a consequence the production of cracked eggs.

The third stage, consists of the $11^{\text {th }}$ and $12^{\text {th }}$ month of the egg production year, featured by an egg carrying decrease to $68 \%$ and the average number of eggs monthly was 23.02 , followed by maximum egg weight. The number of cracked eggs in this phase was the highest (3.36\%), because of the age of the older layers and if it took a parallel 
trend with extreme high environmental temperatures, the percentage of broken and cracked eggs would be increased.

Table 3

Production performance of the tested layer flocks (Produktionsleistungen in den untersuchten Legehennenbeständen)

\begin{tabular}{|c|c|c|c|c|}
\hline Parameters & I. stage & $\begin{array}{c}\text { Flocks } \\
\text { II. stage } \\
\end{array}$ & III. stage & $\begin{array}{c}\text { Average } \\
\text { (monthly) }\end{array}$ \\
\hline $\begin{array}{l}\text { Number of hens in flock } \\
\text { at the beginning of the year } \\
\text { at the end of the year }\end{array}$ & $\begin{array}{l}18.389 \\
17.498\end{array}$ & $\begin{array}{l}18.412 \\
17.762\end{array}$ & $\begin{array}{l}18.394 \\
17.507\end{array}$ & $\begin{array}{l}18.398 \\
17.589\end{array}$ \\
\hline $\begin{array}{l}\text { Mortality } \\
\text { total mortality of birds } \\
\% \text { of mortality of birds }\end{array}$ & $\begin{array}{l}8.91 \\
4.85\end{array}$ & $\begin{array}{l}650 \\
3.53\end{array}$ & $\begin{array}{r}887 \\
4.82\end{array}$ & $\begin{array}{r}67.42 \\
0.37\end{array}$ \\
\hline $\begin{array}{l}\text { Egg production per hen } \\
\text { first production stage } \\
\text { second production stage } \\
\text { third production stage } \\
\text { average per hen }\end{array}$ & $\begin{array}{r}120.97 \\
119.15 \\
45.45 \\
285.57\end{array}$ & $\begin{array}{r}132.73 \\
125.32 \\
44.95 \\
303.00\end{array}$ & $\begin{array}{r}138.94 \\
129.04 \\
47.72 \\
315.70\end{array}$ & $\begin{array}{l}26.18 \\
\mathbf{2 4 . 9 0} \\
23.02 \\
25.12\end{array}$ \\
\hline $\begin{array}{l}\text { Broken \& cracked eggs/annum, \% } \\
\text { first production stage } \\
\text { second production stage } \\
\text { third production stage }\end{array}$ & $\begin{array}{l}0.93 \\
2.37 \\
3.36\end{array}$ & $\begin{array}{l}1.96 \\
3.20 \\
3.41\end{array}$ & $\begin{array}{l}1.01 \\
2.02 \\
3.30\end{array}$ & $\begin{array}{l}1.29 \\
2.53 \\
3.36\end{array}$ \\
\hline $\begin{array}{l}\text { Feed consumption } \\
\text { average consumption per hen/annum, } \mathrm{kg} \\
\text { average consumption daily, } \mathrm{g} \\
\text { average production per egg, } \mathrm{g}\end{array}$ & $\begin{array}{r}43.18 \\
118.30 \\
151.20\end{array}$ & $\begin{array}{r}43.68 \\
119.67 \\
144.16\end{array}$ & $\begin{array}{r}42.37 \\
116.08 \\
134.24\end{array}$ & $\begin{array}{r}43.08 \\
118.02 \\
143.19\end{array}$ \\
\hline $\begin{array}{l}\text { Body weight of hen } \\
\text { at the beginning, } g \\
\text { at the end, } g \\
\text { total weight gain, } g\end{array}$ & $\begin{array}{r}1.820 \\
2.005 \\
185\end{array}$ & $\begin{array}{r}1.800 \\
2.182 \\
382\end{array}$ & $\begin{array}{r}1.730 \\
1.995 \\
265\end{array}$ & $\begin{aligned} & 1.783 \\
& 2.061 \\
& 278\end{aligned}$ \\
\hline
\end{tabular}

The figure shows the influence of layer age on the quality of egg production. The younger layers had mostly produced eggs with less cracks at the beginning of laying, while the older layer at the end of their laying had low egg production and the number of cracked eggs was growing. All this means that as hen age increased egg quality was lower and the strength of eggshell decreased.

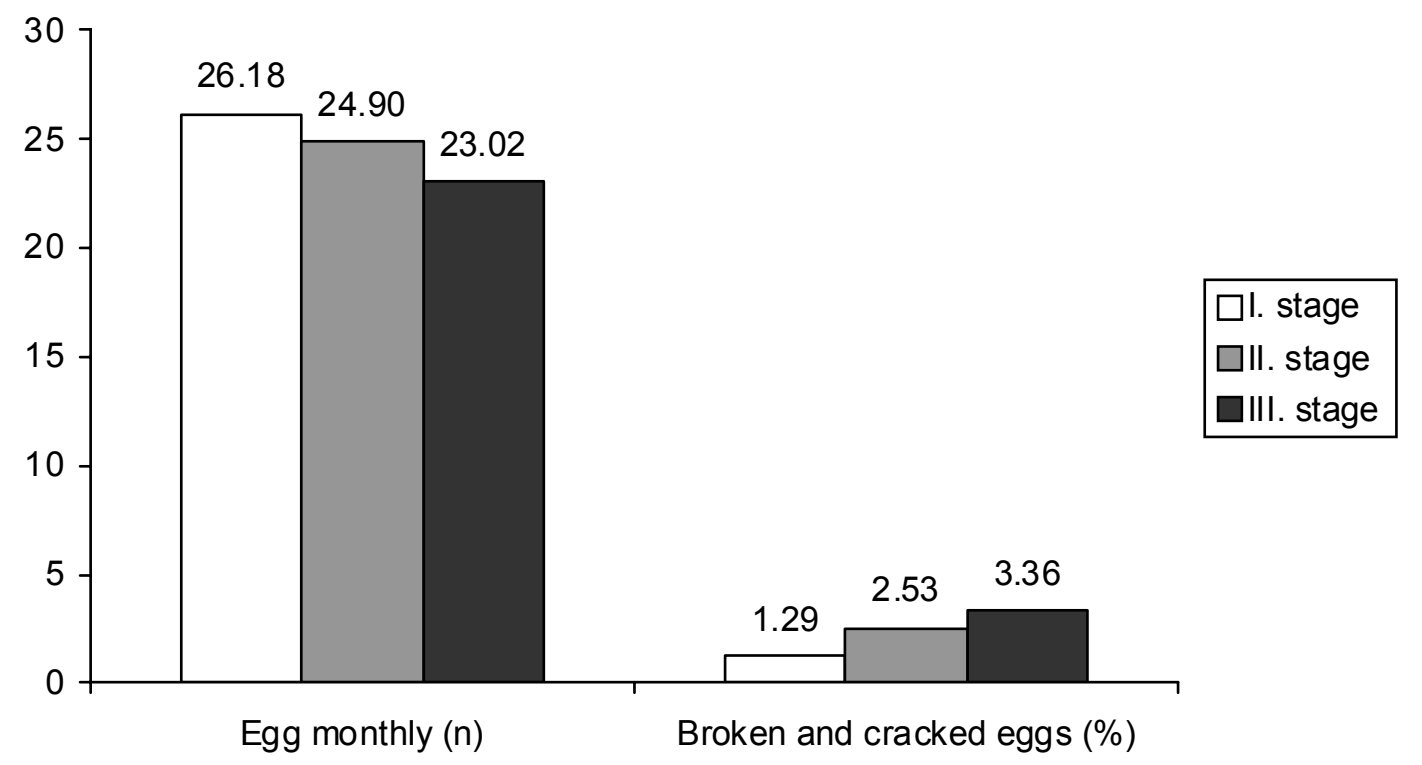

Fig. 1: Monthly average production of eggs and percentage of broken and cracked eggs dependent on the stage of the hens' laying period (Monatliche Legeleistung und prozentualer Anteil an Bruch- und Knickeiern in Abhängigkeit von der Legephase der Hennen) 
During the research 877 eggs were investigated in order to consolidate the effect of hen age (AGE HEN) and season (SEZ) on egg mass (MJ), eggshell weight (LMT) and proportional content of calcium carbonate $\left(\mathrm{LCaCO}_{3}\right)$ in the eggshell. Following statistical analysis a table was created (Table 4) in which the importance of the influences of the factors determined is illustrated.

Table 4

Effect of hen age and season on egg mass, eggshell weight and percentage of calcium carbonate in the eggshell (Einfluss vom Alter der Hennen und von der Jahreszeit auf die Eimasse, Eischalenmasse und den prozentualen Kalziumkarbonatgehalt in der Schale)

\begin{tabular}{|c|c|c|c|c|c|c|c|}
\hline \multirow[b]{2}{*}{ Fixed factor } & \multirow[b]{2}{*}{$\mathrm{n}$} & \multicolumn{2}{|c|}{ MJ, g } & \multicolumn{2}{|c|}{$\mathrm{LMT}, \mathrm{g}$} & \multicolumn{2}{|c|}{$\mathrm{LCaCO}, \%$} \\
\hline & & LSM & SE & LSM & $\mathrm{SE}$ & LSM & SE \\
\hline $\bar{\mu}$ & 877 & 64.62 & 0.085 & 8.21 & 0.036 & 92.21 & 0.195 \\
\hline \multicolumn{8}{|l|}{ Age hen } \\
\hline young & 438 & 64.62 & 0.124 & 8.22 & 0.055 & 91.79 & 0.290 \\
\hline old & 439 & 64.63 & 0.125 & 8.23 & 0.071 & 92.62 & 0.290 \\
\hline Fexp & & \multicolumn{2}{|c|}{0.008} & \multicolumn{2}{|c|}{0.11} & \multicolumn{2}{|c|}{3.70} \\
\hline \multicolumn{8}{|l|}{$S E Z$} \\
\hline Summer & 279 & 62.46 & 0.152 & 8.17 & 0.085 & 90.74 & 0.436 \\
\hline Autumn & 297 & 65.71 & 0.150 & 8.22 & 0.073 & 92.01 & 0.391 \\
\hline Winter & 301 & 65.71 & 0.151 & 8.23 & 0.071 & 93.86 & 0.357 \\
\hline Fexp & & \multicolumn{2}{|c|}{$156.32 * *$} & \multicolumn{2}{|c|}{0.14} & \multicolumn{2}{|c|}{$15.63 * *$} \\
\hline
\end{tabular}

MJ = Egg mass; LMT = Eggshell weight; LCaCO = Calcium Carbonate; LSM = Least Squares Means; SE = Standard error, ${ }^{* *} \mathrm{p}<0.01$

The season had a highly significant effect on egg mass, so that in the summer period a mass value was achieved that was $2.16 \mathrm{~g}$ lower than the overall average. This proves that in the summer period the hens were producing eggs of lower mass. The extremely high temperatures reduced layer appetite, resulting in them not being able to take in all of their nutrient requirement and thus they produced smaller eggs.

The influence of the factor season on eggshell weight did not achieve a significant difference, although in summer months eggshell mass was also lighter $(8.17 \mathrm{~g})$, while in winter months it was heavier $(8.23 \mathrm{~g})$, thus these difference were not significant.

The influence of season on calcium carbonate content of the eggshell attained a very high level of statistical significance. The greatest difference from the average values appeared in the summer months, when the percentage of calcium carbonate was the lowest $(90.74 \%)$ and whilst in the winter months the highest percentage was $(93.86 \%)$.

\section{Discussion}

As previously mentioned, high ambient temperatures and high relative humidity, leads to the depression of feed consumption and reduced layer performance, (STURKIE, 1946), body weight (PINGEL et al., 1995) and a decrease in the evaporated heat losse in layers, aspired to decrease the body temperature (SYKES and FATAFTAN, 1986;). Also with Japanese quails the values of some blood parameters, egg productivity, egg weight and eggshell thickness were found important statistically lower at high environmental temperature (OZCELIK and OZBEY, 2004).

Egg mass depends of hereditary traits, hen age, season and feed consumption (STADELMAN and PRATT, 1989; MACHAL and SIMEONOVOVA, 2002). The results have illustrated more influence of external temperatures on egg mass in contrast to hen age (MACHAL and SIMEONOVOVA, 2002). DEATON et al. (1982) showed that egg mass reduced in the summer period at constant temperatures of 15-35, 
to $2 \mathrm{~g}$ in the younger hens and to $1 \mathrm{~g}$ in the older hens, dependent on the average egg mass. The authors PEGURI and COON (1991) established that the significant decrease in layer appetite, egg mass decreased from $11 \mathrm{~g}$ daily by $1.82 \mathrm{~g}$ when external temperature increased to 31 . In this research there were almost no differences in eggshell weight in the young and adult hens, which did not correspond with most conclusions by authors who have claimed that with the aging of hens the eggshell weight increased. However, all this can be explained by the fact that layers have limit for calcium retention which amounts to $50 \%$ from the total food intake. The average retention is around $2.2 \mathrm{~g}$ calcium. This quantity of $\mathrm{Ca}$ is distributed in the eggshell through the process of egg formation. Because of the fact that as younger layers produce smaller eggs, then it followed that these eggs have a very strong eggshell, because the $2.2 \mathrm{~g}$ calcium is allocated to a smaller area. But with the aging of layers, they lay larger eggs and the same quantity of calcium is allocated to a larger area, which results in the formation of a thinner eggshell.

In conditions of relative humidity from 40 to $70 \%$ and high temperature (25-35 ) it has been concluded that there is a significant decrease in egg mass, eggshell weight and shell thickness as well as a significant increase in cracked eggs. (YAHAV et al., 2000). KERMANSHAHI and GOLIAN (1991) had showed that eggshell thickness, specific weight and percentage of eggshell decreased with hen aging. Selection would need to provide results in increasing eggshell quality with the aim of reducing the number of cracked eggs.

The influence of season on the calcium carbonate content in eggshells was shown to be highly significant $(\mathrm{p}<0.01)$. A $3.12 \%$ difference between the summer and winter season proves that problems relating to eggshell construction quality happened in conditions of high temperatures and heat stress. BRAGG et al. (1971) considered that factors such as reduced calcium secretion, reduced calcium transportation in the eggshell gland, or a decline in the value of bicarbonate ions under the influence of respirator alkaloses, may be closely related to the decline in eggshell quality during periods with high temperatures (OZCELIK and OZBEY, 2004).

Excessive heat during summer results in small eggs or eggs with poor shell quality, because high environmental temperature reduces hen appetite (SAUVEUR and PICARD, 1987; WEBSTER, 2002). Appetite reduction is not only a consequence of heat stress. Hens pant and evaporate water from the respiratory tract and thus carbon dioxide is removed from the blood at a higher rate than normal. There is a change in the acid-base balance of the blood to a higher $\mathrm{pH}$ and carbonate ions become less available to form calcium carbonate, which is the major component of the eggshell. Excessive panting can contribute to reduced shell quality (MULLER, 1966).

The major negative effect of heat stress is presented as decreased feed consumption, which is the reason for the reduced processing of calcium in the organism. Inadequate quantity of available calcium is the most important affect for the decline of egg mass, eggshell weight and decreased eggshell quality (ROLAND et al., 1996).

It can be concluded that the influence of the summer season, especially high temperatures, had negative effects on eggshell quality and with that, it had negative effects on overall egg production in that period of the year, while aging of layers effected a decline in calcium retention and an increase in the number of broken and cracked eggs. 


\section{References}

AL-BATSHAN, H.A.; SCEIDELER, S.E.; BLACK, B.L.; GARLICH, J.D.; ANDERSON, K.E.:

Duodenal calcium uptake, femur ash and eggshell quality decline with age and increase following molt.

BELL, D.:

Poultry Sci. 73 (1994), 1590-1596

Eggshell quality-its impact on production, processing and marketing economics; in: Biotechnology in the Feed Industry. Proceedings of Alltech's $14^{\text {th }}$ Annual Symposium (1998), 447-466

BRAGG, D.B.; FLOYD, J.; STEPHENSON, E.L.:

Factors affecting the transfer of calcium from the hen's diet to the egg shell. Poultry Sci. 50 (1971), $167-173$

DEATON, J.W.; REECE, F.N.; Mc.NAUGHTON, J.L.,; LOTT, B.D.:

Effect of heat stress on laying hens acclimated to cyclic and constant temperature. Poultry Sci. 61 (1982), 875-878

ELAROUSSI, M.A.; FORTE, L.R.; EBER, S.L.; BIELLIER, H.V.:

Calcium homeostasis the laying hen. 1. Age and dietary calcium effects. Poultry Sci. 73 (1994), 25901595

FLOCK, D.K.:

Neue Akzente für die Legehennenzucht: rückläufige Leistungssteigerungen zwingen zum Überdenken der Zuchtziele. Arch. Tierz. 38 (1995), 479-488

HARVEY, W.R.:

User's guide for LSMLMW and MIXMDL, PC-2 VERSION, 1990

KERMANSHAHI, H.; GOLIAN, A.G.:

Effects of various sources of calcium upon eggshell quality and laying hen performance. Proceedings of the $4^{\text {th }}$ European Symposium on the Quality of Eggs and Egg Products, Doorwerth, Holland (1991), $147-158$

KESHAVARZ, K.:

Laying hens respond differently to high dietary levels of phosphorus in monobasic and dibasic calcium phosphate. Poult. Sci. 73 (1994), 687-703

MACHAL, L.; SIMEONOVOVA, J.:

The relationship of shortening and strength of eggshell to some egg quality indicators and egg production in hens of different initial laying lines. Arch. Tierz. 45 (2002), 287-296

MULLER, W.J:

Effect of rapid temperature changes on acid-base balance in shell quality (abstract). Poultry Sci. $\mathbf{4 5}$ (1966), 1109

NYS, Y.; HINCKE, M.; ARIAS, J.L.; GARCIA-RUIZ, J.M.; SOLOMON, S.E.:

Avian eggshell mineralization. Poultry Avian Biol. Rev. 10 (1999), 142-166

OZCELIK, M.; OZBEY, O.:

The effect of the high environmental temperature on some blood parameters and the laying performance of Japanese quails with different body weight. Arch. Tierz. 47 (2004), 93-98

PEGURI, A.; COON, C.:

Effect of temperature and dietary energy on layer performance. Poultry Sci. 70 (1991), 126-138

PINGEL, H.: HAILU, C.; HANH, D.T.; AL-MAHROUS, M.; LENGERKEN VON, G.:

Effect of selection for plasma corticosterone level and feed conversion ration in dwarf White Rocks and adaptability to hot temperature during growth. Arch. Tierz. 38 (1995), 503-511

ROBERTS, J.R:

Factors Affecting egg internal quality and eggshell quality in laying hens. J. Poult. Sci. 41 (2004), 161-177

ROBERTS, J.R.; BLANEY, C.N.:

Eggshell ultrastructure and shell quality. Relationship of ultrastructure to eggshell quality and strength. World's Poult. Sci. Rev. (2000) Conference Montreal Canada

ROLAND, D.A.; BRYANT, M.M.; RABON, H.W.:

Influence of calcium and environmental temperature on performance of first cycle commercial Leghorns. Poultry Sci. 75 (1996), 62-68

SEELAND, G.; HÜBNER, R.; RÖDER, B:

Beziehungen zwischen der Legeleistung und Eiqualitätsmerkmalen von Legehennen. Arch. Tierz. 38 (1995), 489-501

STADELMAN, W.J.; PRATT, D.E.:

Factors influencing composition of the hen's egg. World's Poult. Sci. J. 45 (1989), 247-266

STURKIE, P.D:

The effects of hypotermia upon the reproductive tract of the hen. Poultry Sci. 25 (1946), 369-378

SUMMERS, J.D.; LEESON, S:

Factors influencing early egg size. Poultry Sci. 62 (1983), 1155-1159 
SUVEUR, B.; PICARD, M.:

Environmental effect on egg quality, in: Egg Quality-Current Problems and Recent Advances. R.G. Wells and C.G. Belayavin, et Butterworths, London, UK (1987), 219-234

SYKES, A.H.; FATAFTAN, A.R.A.:

Effect of change in environmental temperature on heat tolerance in laying fowl. Br. Poult. Sci. 27 (1986), 307-316

WEBSTER, A.B.:

Things to remember to preserve egg quality during summer. The University of Georgia Cooperative Extension Service, College of Agricultural and Environmental Science, Athens, Georgia (2002), 42624356

YAHAV, S.; SHINDER, D.; RAZPAKOVSKI, V.; RUSAL, M.; BAR, A.:

Lack of response of laying hens to relative humidity of high ambient temperature. Br. Poult. Sci. 41 (2000), 660-663

\author{
Authors: \\ Dr. NEDELJKA NIKOLOVA* \\ Department of Poultry Science \\ Institute of Animal Science \\ Ile Ilievski 92a \\ P.Box 207 \\ 1000 Skopje \\ Republic of Macedonia \\ Dr. ZLATICA PAVLOVSKI \\ Department of Poultry Husbandry \\ Institute for Animal Husbandry \\ Autoput 16 \\ 11081 Zemun-Beograd \\ Republic of Serbia \\ Prof. Dr. NIKO MILOŠEVIĆ \\ Department of Animal Breeding \\ Faculty of Agriculture \\ Bul. D. Obradovica 8 \\ 21000 University in Novi Sad \\ Republic of Serbia \\ Prof. Dr. MARTIN WAEHNER \\ Department of Agriculture \\ Anhalt University of Applied Sciences \\ Strenzfelder Allee 28 \\ 06406 Bernburg \\ Germany \\ *Corresponding author \\ email: nikned1959@yahoo.com
}

